\title{
The Missing Point Of Knowledge Management in PFI Projects
}

\author{
Kumalasari Kipli ${ }^{1}$, Assoc. Prof. Sr. Dr. Fadhlin Abdullah ${ }^{2} \&$ Dr Fara Diva Mustafa ${ }^{3}$ \\ ${ }^{1}$ Faculty of Built Environment, UTM, Johor \& Faculty of Architecture, Planning \& Surveying, UiTM Sarawak \\ ${ }^{2,3}$ Faculty of Built Environment, UTM, Johor
}

\begin{abstract}
The Private Finance Initiative (PFI) procurement model is a complex system which includes long-term commitment; customers' satisfaction and through-life collaborative working. The projects based on this type of procurement has start from the year 1992 in the UK and year 2006 in Malaysia. Along the process, the PFI projects face few problems despite its advantages. These problem has effected the projects performance such as delay and cost overruns. It seems that the problems occurred are repeatable despite many types of research delved into solving the issues. This paper seeks, to find out the most common problems occur in PFI projects and highlights the best solution to tackle the problems. It also looks at whether similar problems occur in Malaysian construction industry. This research has summarised and critically review the literature on the repeated issues and problem in PFI projects which effect the performance of the projects in term of time, quality and money. It was found that similar problems occur and that similar suggestions were proposed. This shows that the proposed solutions have weaknesses somewhat and hence need to enhance further. This research highlighted the potential of incorporating knowledge management concept through its elements to address the problems. Finally, the paper proposes recommendations to improve the performance of PFI projects with the enhancement of knowledge management especially at the initial and planning stage up to bidding stage where the problem reviewed in the literature always occurred
\end{abstract}

Keywords: PFI Issues, Importance of KM, Performance of PFI

\section{Introduction}

A construction project is a complex process that integrates interests of a large number of stakeholders towards the eventual goal of realizing a constructed facility (Oyegoke et al. 2009; Brown et al. 2001). A construction project is organized through varied linkages throughout its life cycle (Bower 2003). Procurement links the highly fragmented supply side of the construction industry (e.g., engineers, architects, contractors, builders, surveyors, suppliers, and laborers) with the less fragmented demand side (e.g., project owners and representatives) (Cox and Townsend 1998). There is various procurement use in the construction industry; these includes conventional, design and build, negotiation, partnering, public, private partnership and Private Finance Initiative (Lædre, et al., 2006). Originated in England in the year 1992 under the United Kingdom's Tory-led government of John Major (Williams, 2005), PFI is a type of Public_Private Partnerships (PPP) (Akintoye, et al. 2001). The rationale of PFI is to combine the resources of the public and private sectors to provide more efficient public services. The Private Finance Initiative is seen as one of the best options for the government to provide facilities and services to the public without waiting longer for the fund Construction Industry Council, 1998). In a PFI procurement, the private sector partner has sole responsibility to get ready the public service such as school or hospital and involved form the bidding stage until construction, in use stage until hand over the back stage. They will also be responsible for the maintenance during in-use stage (Akintola A., Mathias B., 2009).

One reason for the introduction of PFI in Malaysia in the year 2006 is to get the Value for Money in construction projects (Takim et al., 2009). The PFI projects have been successfully implemented in other countries in the world (Takim, R. et al.,2009) for example, like reckons that United Kingdom, Japan, Italy, France, Germany, Australia and USA (Serco, 2007). Starting from 2006, the government in their Ninth Malaysian Plan started to use Public Funding Initiative (PFI) 
as one of their way of procuring public projects. When the government first announced it, RM20 billion was allocated for delivering public projects in various sectors such as transport, housing, health care and education projects via PPP (Ninth Malaysian Plan, 2006) which includes 425 projects. Out of that 425 projects, 357 projects are under the Ministry of Education as shown in Table 1.

As in the year 2013, the government is undertaking 52 projects, with an estimated value of 62.7 billion, which are in the construction stage and some already in the operation stage. The government plans to build seven toll highways, five more Universiti Teknologi MARA branch campuses, the Integrated Transport Terminal in Gombak, privatization of Penang Port and redevelopment of Angkasapuri Complex, Kuala Lumpur as Media City (Tenth Malaysia Plan, 2010). Public Private Partnership Department or Unit Kerjasama Awam Swasta (UKAS) up to December 2014 has completed 698 projects including PFI projects.

\section{Methodology}

The research was conducted using an analysis of literature reviews where all the selected journal papers, theses, reports related with PFI had been review an analysed to find out the issues and problems highlighted by the writers. The problems and issues arise then grouped into categories. From each category then we have identified the pattern of problems and issues and find out the main problems from each category. Issues were then analysed in relation to the usage of knowledge management in their solution of the problems

\section{PFI Nature}

PFI projects involve long-term collaboration and networking across different professional groups such as architects, planners, engineers, surveyors, lawyers, financial specialists, facilities management managers and other team members.
Each party has their specific functional relationship in the PFI projects to deliver services according to the public sector clients' output specification (Robinson, H.S., 2009). Each party carries with them not only their specific job description in the project but also tacit knowledge as the result of their action and not all these tacit knowledge were capture, restore, sharing and transferred for future usage. Usually, it is embedded with the completion of the projects. Here come the important of knowledge management.

Human activity cannot be done smoothly without knowledge. Knowledge scope itself are as wide and varied all the varieties of human pursuits. No human civilisation could have existed without creating, accumulation, sharing and applying knowledge (Chimay J.A. et al., 2005). The economic value of knowledge has been discussing for centuries, from the ancient Greeks to Adam Smith and Alfred Marshall, who in 1890 wrote: 'Capital consist in a great part of knowledge and organisation... Knowledge is our most powerful engine in production' (Marshall, 1972). Windrum et al. (1997) and Den Hertog and Bilderbeek (1998) identified design, architecture, surveying and other construction services as knowledge-intensive service sectors.

In order to perform the duty at their best, skills are important as it is their knowledge and experiences (RICS, 2003). Abdullahi A. Umar, et al. (2014) has come out with a list of important skills needed for practitioners dealing with PFI projects. These skills include Contract design skills, Contract Management skills, and Risk Identification and Management skills. For a very complex project such as PFI, the capability refers to the firm's ability to answer a public invitation to tender by drawing up a competitive bid with a high probability of award, on short notice and while minimizing upfront cost. According to Davies and Brady (2000, p. 31), these capability includes the following activities:

Table 1 PFI projects under Ninth Malaysian Plan

\begin{tabular}{|l|l|l|}
\hline \multirow{3}{*}{$\begin{array}{l}\text { 425 PFI Projects } \\
\text { (based on Ninth Malaysia }\end{array}$} & $\begin{array}{l}357 \text { projects under Ministry of } \\
\text { Education }\end{array}$ & 180 primary schools \\
\cline { 2 - 3 } \begin{tabular}{l} 
Plan) \\
\cline { 2 - 3 }
\end{tabular} & 12 UiTM projects & 177 secondary schools \\
\cline { 2 - 3 } & 2 Youth Training Institution (Institut Latihan Belia) \\
\hline
\end{tabular}


- $\quad$ Ability to collect, compile and extract the customer documents after an invitation to tender received from the customer;

- $\quad$ designing a conceptual design with detail components in the proposed construction products;

- $\quad$ estimation of costs, taking into account many factors (e.g., the quality, reliability and cost of components supplied internally or from different suppliers; project management methodology; productivity, etc.);

- $\quad$ defining levels of service;

- $\quad$ risk management;

- $\quad$ scheduling of project work programs;

- choosing of subcontractors;

- preparing the tender document (including contract documents) by integrating information determined in the previous steps.

The above capabilities reflect that the bidding process for PFI projects requires specialized knowledge from, among others, architects, design engineers, cost consultants, tax consultants, lawyers, facility managers and project managers. To integrate such complementary sets of specialized knowledge, an understanding common to all participants regarding the basic categories and building blocks of the bid (e.g., specifications of the projected buildings, scope of services rendered, level of detail of description) as well as regarding the generic process of bid preparation (e.g., standard operating procedures and "who needs to meet with whom to discuss what and at what stage" Cacciatori, 2008, p. 1595) is paramount.

Managing the knowledge during and after the project implementation is a key challenge posed to construction organisation (Udeaja et al., 2008). The construction organisational competitive advantages depend on the capability to learn and adapt faster than its rivals. This capability is strongly dependent on the ability of the organisation to create, acquire, store and use experiences, knowledge, skills and lesson learnt in the past projects that have the potential to enhance the organisational's future performance (Nonnaka and Von Krogh, 2009). According to Hsiah, et al. (2009) knowledge is vital for effective project implementation, choosing the very best projects, winning bids and also for rganizational efficiency. The 1990s interest in KM initially triggered the response that it was about doing things that were new. More recently many organisations have come to realise that it is also a process of discovery. That is, discovering processes that already happen, such as the sharing of knowledge among communitiest of practitioners, that were rarely if ever labelled 'knowledge management' (Chimay J.A. et al., 2005).

PFI schemes require both broad PFI expertise and specialized knowledge in particular fields. One difficulty, according to some consultants, concerns the fact that professional advice is expensive, and the feebudget can- not be accurately predicted. Subsequently, reaching an agreement regarding the fees may also be problematic (A. Akintote, 2003). PFI seldom used by the client organisation, so they have only a few staff that understand the intricacies of PFI. In contrast, some private sector organisations have been involved with several PFI projects and, therefore, have significantly more experience (Robinson, et al., 2004)

A common problem associated with PFI, which is also related to the lack of knowledge are a delay on client's decision where clients need more time to make decision and longer negotiation period due to lack of PFI experts, and this makes the schedule complete the projects are very tight. Furthermore, because its largescale involved schemes, high levels of investment and risks involved and limited knowledge transfer between PFI projects (Carillo et. Al., 2006). Knowledge management in PFI then should be seen as one of the considerations in PFI projects due to its benefits to the projects (Robinson, et al., 2010).

\section{Analytical Review of Issues and Problem in PFI}

The PFI procurement model is a complex system (Sundaraj \& Eaton, 2013). Still not reaching its tenth years of implementation which started in the year 2006 (Ninth Malaysian Plan 2006), PFI is considered new in Malaysia compared to a country like the United Kingdom, which has started PFI since the year 1992. The eagerness of using PFI procurement for nowadays projects may be influenced by the benefits that said to be gain once using these procurements which are: 1) Time savings which is shorter construction period (Ward and Chapman, 1995; Price, 2000). (2) Cost savings in term of whole-life price of a scheme produced by PFI compared to by traditional means (PFP, 1995; Grub 1998), (3) helping the public sector financially (Beenhakker, 1997; Jones, 1998; Partnership British Columbia, 2003) (4) the whole cost of the project from construction to maintenance stipulated in the contract (Partnership British Columbia, 2003). Optimal use of assets (Partnership British Columbia, 2003).

However, despite the advantages, there are few issues still occurs in the PFI projects. Review of the literature managed to identify few problems which keep occurring in PFI projects. As shown in Table 2 the problems or issues in PFI can be summarised as follows: (1) Issues associated with value for money 2) Lack 
of expertise or professional in PFI projects 3) cost overrun in PFI projects 4) Time overrun/Longer negotiation period 5) Issues with life-cycle costing 6) Aspects of PFI not clear to participants 7)payment deduction 8) Performance of FM in PFI and 8) sustainability of PFI. All these problems and issues have an impact on the performance of the projects whether in term of time, quality or money or even on the three of it. The solution suggested by previous researchers are also tabulated in the table. For example, in the value for money issues, out 12 papers analysed, four of the researchers suggest improving the VfM through assessment model and way of assessing the VfM. Others have their different ways, and only one researcher suggest the use of knowledge management to resolved the VfM issues.

Apparently in every problem or issues syntheses in Table $2 \mathrm{KM}$ element such as the process of capturing, reuse and sharing involved. According to Smyth and Edkins (2007) skills and experiences are tacit knowledge which relates on how individual received and capture new information that they gain and kept it as references for the same future events that might occur. It is not easy to express, highly personal and is in the professional heads. Sharing the knowledge in PFI projects would be difficult especially when the other individual did not have any explicit knowledge of the PFI procurement.

Figure 1 shows how these three elements of KM link together, each of them having a

reciprocal relationship with each of the other two. For example, people help design and then operate Processes, while Processes define the roles of, and the knowledge needed by People. As well as the relationship between the three elements, Figure 1 can also be used to help conceptualise any particular knowledge management initiative, by regarding it as being positioned somewhere in the triangle with the three elements at its vertices. Examples of knowledge management initiatives near the People vertex of the triangle would be implementing directories or communities of practice. Near the Technology Vertex would be implementing repositories or knowledge-based systems. Near the Process vertex would be implementing new ways to work or to build in what you want to achieve, in both cases to achieve knowledge management objectives.

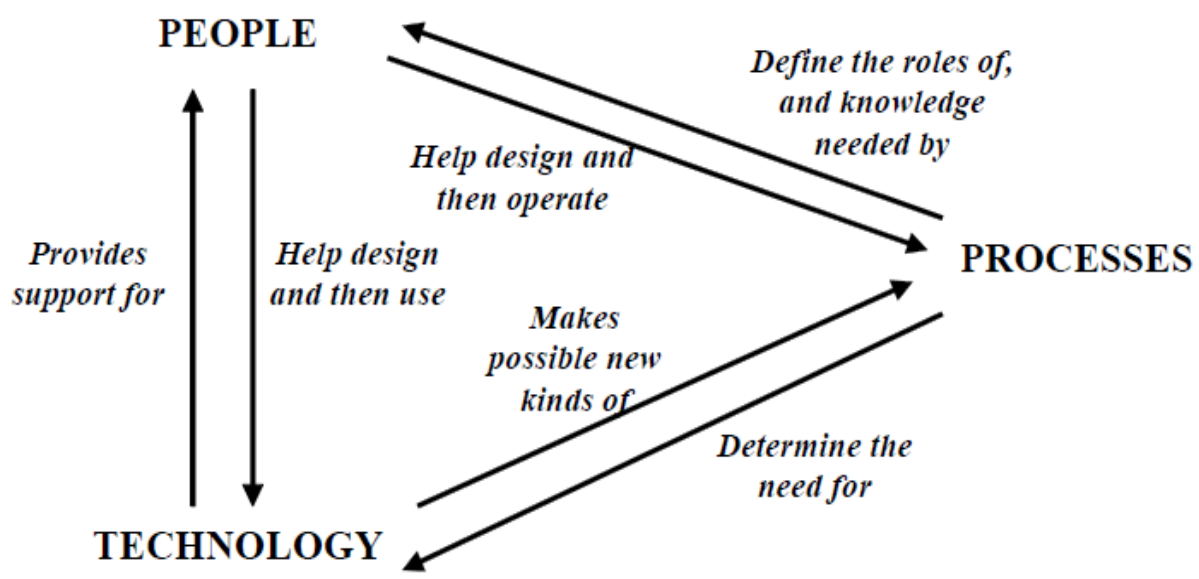

Figure 1 People, processes and technology (Edwards, 2009) 
Table 2 The organisation of problems and issues identified from the literature-showing the repetitions and connection with $\mathrm{K}$

\begin{tabular}{|c|c|c|c|c|c|}
\hline $\begin{array}{l}\text { Issues Prompted from the } \\
\text { synthesis }\end{array}$ & Resolution & Literatures sources & \multicolumn{3}{|c|}{$\begin{array}{l}\text { Performance } \\
\text { effected }\end{array}$} \\
\hline \multicolumn{2}{|l|}{ VALUE FOR MONEY } & & $\mathbf{T}$ & $\mathbf{Q}$ & $\mathbf{M}$ \\
\hline Limitation to achieve VfM & $\begin{array}{l}\text { Improvement on appraisal } \\
\text { and evaluation process }\end{array}$ & $\begin{array}{l}\text { Froud and } \\
\text { Shaoul,(2001) }\end{array}$ & & / & \\
\hline VFM effectiveness & $\begin{array}{l}\text { Suggest design for post- } \\
\text { project evaluation }\end{array}$ & Broadbent, et al, 2003 & & & / \\
\hline $\begin{array}{l}\text { Achieving best value for } \\
\text { PFI projects }\end{array}$ & $\begin{array}{l}\text { New requirements to } \\
\text { achieve the best value } \\
\text { should be introduce }\end{array}$ & Akintoye, et al., 2003 & & & / \\
\hline $\begin{array}{l}\text { Lack of agreed Formulae for } \\
\text { VfM stakeholder to } \\
\text { benchmark VfM }\end{array}$ & $\begin{array}{l}\text { Identifying principle factors } \\
\text { in creating VfM in PFI }\end{array}$ & (Pitt, et al., 2006) & & & / \\
\hline VfM through PSC in PFI & $\begin{array}{l}\text { The need for PSC in } \\
\text { Malaysia context }\end{array}$ & $\begin{array}{l}\text { (S. Ismail \& Rashid, } \\
\text { 2007) }\end{array}$ & & & / \\
\hline $\begin{array}{l}\text { What are details } \\
\text { components of PSC } \\
\text { protocol to evaluate VfM. }\end{array}$ & $\begin{array}{l}\text { Development of VfM } \\
\text { assessment model }\end{array}$ & Takim, et al., 2009 & & & / \\
\hline $\begin{array}{l}\text { What are the factors and } \\
\text { elements for VfM } \\
\text { framework assessment }\end{array}$ & $\begin{array}{l}\text { Identify the VfM criteria for } \\
\text { assessment }\end{array}$ & K. Ismail, et al., 2011 & & & / \\
\hline $\begin{array}{l}\text { Critical parameter } \\
\text { influencing VfM in PFI } \\
\text { projects }\end{array}$ & $\begin{array}{l}\text { list of critical parameters can } \\
\text { help practitioners to identify } \\
\text { priority areas and achieve a } \\
\text { long-lasting VFM. }\end{array}$ & $\begin{array}{l}\text { (Henjewele, Sun, \& } \\
\text { Fewings, 2011) }\end{array}$ & & & / \\
\hline VfM still not achievable & $\begin{array}{l}\text { Knowledge management as } \\
\text { important factor to filling } \\
\text { gap in getting VfM }\end{array}$ & $\begin{array}{l}\text { (Henjewele, et al., } \\
\text { 2012) }\end{array}$ & & & / \\
\hline $\begin{array}{l}\text { The need for VfM } \\
\text { Assessment }\end{array}$ & Model of VfM Assessment & K Ismail, et al., 2012 & & & / \\
\hline VfM success factors & $\begin{array}{l}\text { the knowledge of priority } \\
\text { factors that need to enhance } \\
\text { the achievement of long- } \\
\text { term VFM }\end{array}$ & $\begin{array}{l}\text { (Henjewele et al., } \\
\text { 2012) }\end{array}$ & & & / \\
\hline Checking on VfM & $\begin{array}{l}\text { Economic, environ-mental } \\
\text { and social sustainability sho- } \\
\text { uld be core consi-derations } \\
\text { through-out the lifetime of a } \\
\text { ppp/pfi. }\end{array}$ & $\begin{array}{l}\text { (Semple \& Turley, } \\
\text { 2013) }\end{array}$ & & & l \\
\hline \multicolumn{2}{|c|}{$\begin{array}{l}\text { LACK OF PROFESSIONAL/EXPERT IN PFI } \\
\text { PROJECTS }\end{array}$} & & $\mathbf{T}$ & $\mathbf{Q}$ & $\mathbf{M}$ \\
\hline $\begin{array}{l}\text { The different levels of PFI } \\
\text { experience between onstruc- } \\
\text { tion parties and client }\end{array}$ & $\begin{array}{l}\text { The need for knowledge } \\
\text { transfer }\end{array}$ & Herbert, et al., 2004 & / & / & / \\
\hline $\begin{array}{l}\text { Lack of skills among } \\
\text { practitioners in PFI projects }\end{array}$ & $\begin{array}{l}\text { Enhance the capability and } \\
\text { skills of PFI practitioners }\end{array}$ & $\begin{array}{l}\text { (A. A.Umar, et al., } \\
\text { 2011), (Abdullahi A } \\
\text { Umar, et al., 2014) }\end{array}$ & / & / & / \\
\hline $\begin{array}{l}\text { Lack of skills among } \\
\text { practitioners in PFI projects }\end{array}$ & $\begin{array}{l}\text { The need for knowledge } \\
\text { transfers in PFI projects }\end{array}$ & (Carrillo, et al. 2006a) & / & l & l \\
\hline \multicolumn{2}{|l|}{ COST OVERRUN } & & $\mathbf{T}$ & $\mathbf{Q}$ & M \\
\hline
\end{tabular}


cost and time overrun for health \& transport sectors

cost overruns due to the cost of the specialist expertise required during the bidding stage and the lengthy negotiation periods Cost of PFI procurement still higher Charges usually put at the end of the project, "backend" and the perception that the return of the PFI investors is excessive. Achieving the best value in PFI project

large differences of cost estimate between client and contractor \&high transaction costs of PFI bids;

\section{TIME OVERRUN}

Lack of PFI experts Delay in awarding projects the lengthy negotiation period

The negotiations are lengthy and complex.

\section{LIFE-CYCLE COSTING}

Failure of QS's contractor to consider LCC

Correlation analysis of capital and LCC
Knowledge of priority factors that need to be addressed to enhance the achievement of long-term VFM in PFI projects

To enhance the knowledge and skills especially client because for client organizations, PFI usually their one-off project. Introduction pf PFI2

Come out with the calculation and analysis

achievement of best values requirements through the input of few factors To enhance the knowledge of client organization
(Henjewele et al., 2012)

Carrillo, et al, 2008a)

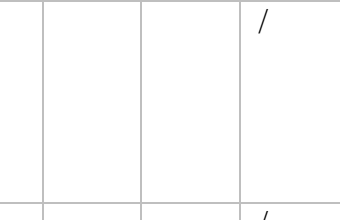

\section{(Abdullahi A Umar et} al., 2014) (Hellowell \& Vecchi, 2012)

(Akintoye et al.,2003.)

Robinson, et al., 2004

(1)

\begin{tabular}{|l|} 
Lack of knowledge transfer \\
\hline Lack of expert
\end{tabular}

Lack of expert

\section{Lack of expertise}

Increased maintenance costs in the future, compared to the original budget for maintenance costs.

Suggest on update of current cost estimate practice, the cost models for LCR costs to be review, surveys are carried out to investigate the issues in cost estimates further

ASPECT OF PFI NOT CLEAR TO PARTICIPANTS

Project technical feasibility $\quad$ The SPV must demonstrate that the technical aspects of a proposal will satisfy all

Clients' briefs inadequate. Clients to improve on the of specification of projects

\begin{tabular}{|l|l|}
\hline PAYMENT DEDUCTION & \\
$\begin{array}{l}\text { Payment deduction due to } \\
\text { performance issue during } \\
\text { operation and maintenance }\end{array}$ & $\begin{array}{l}\text { Model of Critical Success } \\
\text { Factors }\end{array}$ \\
\hline & $\begin{array}{l}\text { to appreciate the value of the } \\
\text { partnersip }\end{array}$ \\
\hline
\end{tabular}

PERFORMANCE OF FM

Performance of FM

Ne

\begin{tabular}{|l|l|l|l|}
\hline (Li, et al., 2005) & T & Q & M \\
\hline Robinson, 2004 & $/$ & $/$ & $/$ \\
\hline $\begin{array}{l}\text { (Oyedele, 2013) } \\
\text { (H. S. Robinson \& }\end{array}$ & T & Q & M \\
\hline $\begin{array}{l}\text { Scott, 2010) } \\
\text { Mustapa, 2013, } \\
\text { Carillo\&Muzani, 2008 }\end{array}$ & & $/$ & $/$ \\
\hline
\end{tabular}




\begin{tabular}{|c|c|c|c|c|c|}
\hline $\begin{array}{l}\text { whether sustainable in } \\
\text { contract doc exist? }\end{array}$ & $\begin{array}{l}\text { need to identify key } \\
\text { elements of sustainable PFI } \\
\text { contract }\end{array}$ & (Farmi,et al, 2011b) & I & / & / \\
\hline $\begin{array}{l}\text { Ambiguity of sustainable } \\
\text { contracts \& poor } \\
\text { implementation of } \\
\text { sustainable green elements }\end{array}$ & $\begin{array}{l}\text { facilitate the process of } \\
\text { promoting sustainability }\end{array}$ & (Farmi, et al, 2011a) & / & / & / \\
\hline
\end{tabular}

For the PFI procurement to success, there is a need for staff with experience in complex procurement with strong knowledge in various area such as technical, commercial and finance (D Tranfield et. al, 2004). As PFI projects itself is very complex, J. Kamara (2012) highlight that to ensure the integration in project development process, there is a need to enhance on the knowledge management gap first.

Figure 2 show the summary of the analytical analysis of literature review issues or problems arises in relation with PFI.

\section{SUMMARY OF ANALYTICAL REVIEW OF LITERATURE}

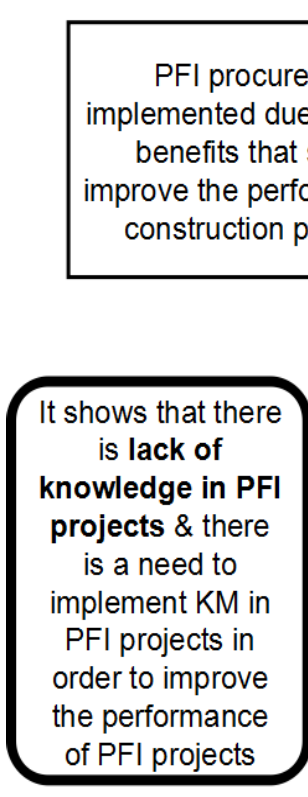

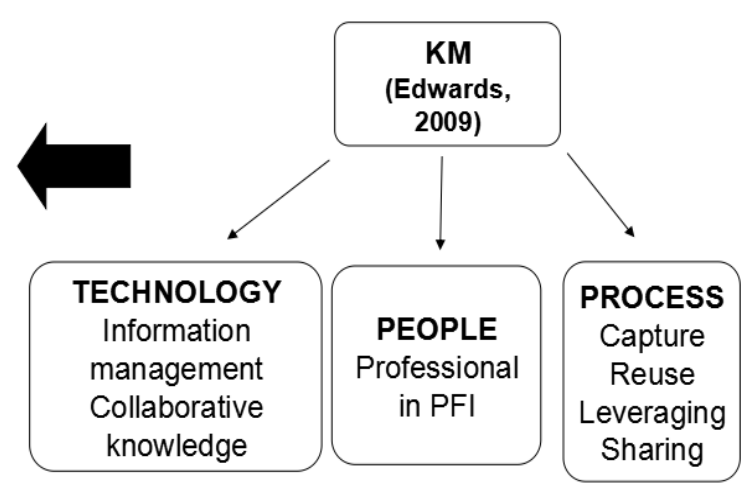

These problems can be summarised as:

1) value for money 2)Lack of expertise 3) cost \& time overrun 4) LCC 5) Aspect of PFI not clear 6)payment deduction 8) performance of FM 9) sustainability

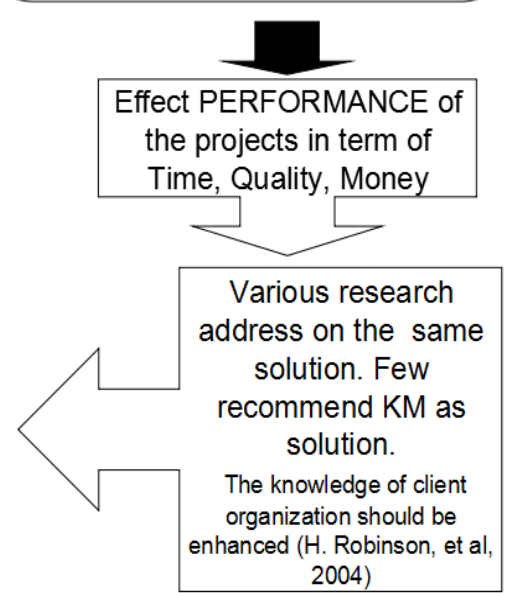

Figure 2: Summary of Analytical Review of Literature

\section{Management Process}

To leverage upon the knowledge infrastructure capability (people, process and technology), KM processes need to be properly in place so that knowledge can be captured, stored, shared and applied effectively (Davenport et al., 1996; Grant,

Table 3 shows the stages identified by different researchers.
1996; Leonard, 1995). Knowledge management process involved different stages, and different researchers have their own knowledge management process. 
Table 3 Knowledge Management Process (Addition to H.C. Tan, et al., 2010)

\begin{tabular}{|c|c|c|c|c|c|c|}
\hline $\begin{array}{l}\text { Robinson, et } \\
\text { al. }(2001)\end{array}$ & $\begin{array}{l}\text { Kululanga } \\
\text { and } \\
\text { McCaffer } \\
(2001)\end{array}$ & Bhatt (2001) & $\begin{array}{l}\text { Marquadt } \\
\text { (1996) }\end{array}$ & $\begin{array}{l}\text { Gold et al. } \\
\text { (2001) }\end{array}$ & $\begin{array}{l}\text { Herbert } \\
\text { Robinson, } \\
\text { et. al, (2010) }\end{array}$ & $\begin{array}{l}\text { Rollett } \\
(2003)\end{array}$ \\
\hline $\begin{array}{l}\text { Discovering } \\
\text { Locating } \\
\text { Capturing } \\
\text { Organising } \\
\text { Storing } \\
\text { Sharing } \\
\text { Transferring } \\
\text { Modifying } \\
\text { Applying } \\
\text { Archiving } \\
\text { Retirement }\end{array}$ & $\begin{array}{l}\text { Acquiring } \\
\text { Creating } \\
\text { Storing } \\
\text { Sharing } \\
\text { Utilising }\end{array}$ & $\begin{array}{l}\text { Creating } \\
\text { Presentation } \\
\text { Validating } \\
\text { Distributing } \\
\text { Applying }\end{array}$ & $\begin{array}{l}\text { Acquisation } \\
\text { Creation } \\
\text { Storage } \\
\text { Transfer } \\
\text { utilisation }\end{array}$ & $\begin{array}{l}\text { Acquisition } \\
\text { conversion } \\
\text { application } \\
\text { protection }\end{array}$ & $\begin{array}{l}\text { Discovering } \\
\text { capturing } \\
\text { Archiving } \\
\text { retirement } \\
\text { Creation and } \\
\text { leverage } \\
\text { Distribution } \\
\text { and sharing } \\
\text { Organisation } \\
\text { and Storage }\end{array}$ & $\begin{array}{l}\text { Planning } \\
\text { Creating } \\
\text { Assessing } \\
\text { Integrating } \\
\text { Organising } \\
\text { Transferring } \\
\text { Maintaining }\end{array}$ \\
\hline
\end{tabular}

Applying all the KM process throughout the stages of PFI is very important as it is one of the element in KM that can enhance the performance of the project in term of time, quality and money.
There are few types of research were done regarding the knowledge management in PFI and highlighted the importance of knowledge management (refer

\section{Knowledge Management in PFI}

Table 4).

Table 4List of knowledge management researches done in PFI

\begin{tabular}{|c|c|c|}
\hline Author & The importance of knowledge & KM involved \\
\hline $\begin{array}{l}\text { P. M. Carrillo, } \\
\text { et al., } 2006\end{array}$ & $\begin{array}{l}\text { One way of improving PFI performance is to transfer knowledge } \\
\text { from previous projects on to future projects and other PFI teams. He } \\
\text { and the team then developed a framework of knowledge transfer } \\
\text { based on one of the challenges faced by the construction organisation } \\
\text { involved in PFI. }\end{array}$ & $\begin{array}{l}\text { Knowledge } \\
\text { transfer }\end{array}$ \\
\hline $\begin{array}{l}\text { Liyanage, et } \\
\text { al., } 2009\end{array}$ & $\begin{array}{l}\text { An empirical study on assessing the process of knowledge transfer in } \\
\text { PFI. }\end{array}$ & $\begin{array}{l}\text { Knowledge } \\
\text { transfer }\end{array}$ \\
\hline $\begin{array}{l}\text { Kwawu, et al. } \\
2010\end{array}$ & $\begin{array}{l}\text { Identified barriers and enablers for knowledge transfer in PFI. They } \\
\text { said that practitioners and managers can efficiently design knowledge } \\
\text { transfer framework that can be used to overcome the barriers } \\
\text { encountered while enhancing the enablers to improve knowledge } \\
\text { transfer processes. }\end{array}$ & $\begin{array}{l}\text { Knowledge } \\
\text { transfer }\end{array}$ \\
\hline $\begin{array}{l}\text { (Robinson, et } \\
\text { al., 2010.) }\end{array}$ & $\begin{array}{l}\text { Governance \& knowledge management for Public-Private } \\
\text { Partnership/ Private Finance Initiative }\end{array}$ & $\begin{array}{l}\text { Knowledge } \\
\text { management as a } \\
\text { whole }\end{array}$ \\
\hline $\begin{array}{l}\text { (Kamara, } \\
\text { 2012) }\end{array}$ & $\begin{array}{l}\text { The need for robust information exchange and knowledge } \\
\text { management systems to ensure true lifecycle integration of building } \\
\text { information and activities, especially in bridging the gap between } \\
\text { client and construction organizations involved in the creation and } \\
\text { management of buildings. }\end{array}$ & $\begin{array}{l}\text { Knowledge } \\
\text { management as a } \\
\text { whole }\end{array}$ \\
\hline
\end{tabular}




\begin{tabular}{|l|l|l|}
\hline Author & The importance of knowledge & KM involved \\
\hline $\begin{array}{l}\text { (Hecker, } \\
2012)\end{array}$ & $\begin{array}{l}\text { The need for collective knowledge in procurement as complex as PFI } \\
\text { to ensure the interrelationship and interaction will integrate along the } \\
\text { PFI processes. }\end{array}$ & $\begin{array}{l}\text { Collective } \\
\text { knowledge }\end{array}$ \\
\hline $\begin{array}{l}\text { (Mustapa, } \\
\text { \& Mustapa } \\
\text { 2008 }\end{array}$ & The importance of knowledge management in FM in PFI projects & $\begin{array}{l}\text { Knowledge } \\
\text { management as a } \\
\text { whole }\end{array}$ \\
\hline
\end{tabular}

Most of the researches are done in other countries like UK, Australia, Japan and Hong Kong, which are the developed country. In this research context would be PFI knowledge in Malaysia. From the studies undertaken by previous researchers as discussed above, the practice of $\mathrm{KM}$ is important in the PFI projects as it would improve the performance of the projects. Hence, this strengthens the reason to fill in the gap with the implementation of KM in PFI projects.

In Malaysia, there is various research concerning on PPP/PFI had been done, but little research directly on the knowledge management of PFI. Some of the research that had been done are regarding acceptability of PFI in Malaysia (Takim, R., 2009), framework of assessment for value for money (K. Ismail, et al, 2011), key performance indicators for PFI in Malaysia (Syuhaida Ismail, 2009; Mohd Rayme A.M., 2009), delay in awarding PFI project (Mohd Asrul,2009), issues related to the Public Sector Comparator (PSC) in PFI (S. Ismail \& Rashid, 2007), and about the skills of professional involved in PFI (Umar, et al, 2014).

Since the conditions, performance and the nature of the construction organisation have implications for the implementation of KM, KM implementation should be considered in the context of a specific organisation. Malaysia has its way of conducting the procurement (Nurshuhada, et al., 2013). Therefore, the self-styled prescription is required considering the uniqueness of Malaysia PFI projects. A specific KM implementation framework is required for KM implementation in PFI projects in Malaysia. For this reason, further research focuses on developing a KM implementation framework, creating awareness of the KM to sustain highly skilled personnel at all stages of the PFI projects and to improve the PFI projects' performances.

\section{Conclusion and Recommendation}

PFI procurement introduces by the government to brings a lot of benefits that is said to be a gain in the projects. However, problems or issues in PFI still keep recurring. Some of the solutions recommend on the use of knowledge but some still focusing on the same things. The study concludes that there is an urgency to consider the full use of $\mathrm{KM}$ in PFI projects which apparently the usage can be enhanced. Future research is expected to study further the current status and level of implementation of knowledge management in PFI projects in Malaysia. Further study should also be done to find out the barriers and success factors for implementation of KM in PFI projects in Malaysia.

\section{References}

1. Accountability, F. (2012). An Evaluation of the Projected Returns to Investors on 10 PFI Projects Commissioned by the National Health Service, 28(February).

2. Akintoye, A., Hardcastle, C., Beck, M., \& Chinyio, E. (n.d.). Achieving best value in private finance initiative project procurement Achieving best value in private finance initiative project procurement, (November 2014), 37-41. doi:10.1080/0144619032000087285

3. Broadbent, J., Gill, J., \& Laughlin, R. (2003). Evaluating the Private Finance Initiative in the National Health Service in the UK. Accounting, Auditing \& Accountability Journal, 16(3), 422445. doi:10.1108/09513570310482309

4. Brown, D., Ashleigh, M., Riley, M., Shaw, R., 2001. New Project Procurement Process. Journal of Management in Engineering 17, 192-201.

5. Carrillo, P. M., Robinson, H. S., Anumba, C. J., \& Bouchlaghem, N. M. (2006a). A Knowledge Transfer Framework: the PFI context. Construction Management and Economics, 24(10), 1045-1056. doi:10.1080/01446190600799224

6. Carrillo, P. M., Robinson, H. S., Anumba, C. J., \& Bouchlaghem, N. M. (2006b). A Knowledge Transfer Framework: the PFI context. Construction Management and Economics, 24(10), 1045-1056. doi:10.1080/01446190600799224

7. Carrillo, P. M., Robinson, H. S., Anumba, C. J., \& Bouchlaghem, N. M. (2006c). A Knowledge Transfer Framework: the PFI context. Construction Management and Economics. doi:10.1080/01446190600799224 
8. Carrillo, P. M., Robinson, H. S., Anumba, C. J., \& Nasreddine, M. (n.d.). Construction Management and Economics A Knowledge Transfer Framework: the PFI context A Knowledge Transfer Framework: the PFI context, (December 2014), 37-41. doi:10.1080/01446190600799224

9. Carrillo, P., Robinson, H., Foale, P., Anumba, C., \& Bouchlaghem, D. (2008). Participation, Barriers, and Opportunities in PFI: The United Kingdom Experience, (July), 138-145.

10. Cox, A.; Townsend, M. (1998). "Strategic Procurement in Construction; towards better practice in the management of construction supply chains". London. Thomas Telford.

11. Delay approval in private finance initiative (pfi) project in malaysia mohd asrul bin adnan universiti teknologi malaysia. (n.d.).

12. Farmi, M., Che, I., Ismail, Z., Hassan, F., \& Mat, M. C. (2011a). Fundamental Elements of Sustainable Private Financing Initiative Contracts, 334-339.

13. Farmi, M., Che, I., Ismail, Z., Hassan, F., \& Mat, M. C. (2011b). Sustainable Private Financing Initiative Contracts, 452-457.

14. Hecker, A. (2012). Knowledge Beyond the Individual? Making Sense of a Notion of Collective Knowledge in Organization Theory. doi:10.1177/0170840611433995

15. Henjewele, C., Sun, M., \& Fewings, P. (2011). Critical parameters are influencing value for money variations in PFI projects in the healthcare and transport sectors. Construction Management and Economics, 29(8), 825-839. doi:10.1080/01446193.2011.592204

16. Henjewele, C., Sun, M., \& Fewings, P. (2012). Analysis of factors affecting value for money in UK PFI projects. Journal of Financial Management of Property and Construction, 17(1), 9-28. doi:10.1108/13664381211211028

17. Ismail, K., Takim, R., \& Nawawi, A. H. (2011). The evaluation criteria of Value for Money (VFM) of Public Private Partnership (PPP) bids. International Conference on Intelligent Building and Management, 5(November), 349-355.

18. Ismail, S., \& Rashid, K. A. (2007). Private Finance Initiative (PFI) in Malaysia: the Need for and Issues Related to the Public Sector Comparator (PSC). Jurnal Akuntansi Dan Keuangan Indonesia. Retrieved from http://journal.ui.ac.id/index.php/jaki/article/view/28 88

19. Kamara, J. M. (2012). Integration in the project development process of a Private Finance Initiative (PFI) project. Architectural Engineering and Design Management, 8(4), 228-245. doi:10.1080/17452007.2012.666729
20. Lædre, O., Austeng, K., Haugen, T. I., \& Klakegg, O. J. (2006). Procurement Routes in Public Building and Construction Projects. Journal of Construction Engineering and Management, 132(7), 689-696. doi:10.1061/(ASCE)07339364(2006)132:7(689)

21. Li, B., Akintoye, a., Edwards, P. J., \& Hardcastle, C. (2005). Perceptions of positive and negative factors influencing the attractiveness of PPP/PFI procurement for construction projects in the UK: Findings from a questionnaire survey. Engineering, Construction and Architectural Management, 12(2), 125-148. doi:10.1108/09699980510584485

22. Liyanage, C., Ballal, T., \& Elhag, T. (2009). Assessing the process of knowledge transfer - An empirical study, $8(3)$. doi:10.1142/S0219649209002373

23. Mustapa, M. (2013). Facilities Management Knowledge in Private Finance Initiative (PFI) Healthcare Projects, 263. Retrieved from https://dspace.lboro.ac.uk/dspacejspui/bitstream/2134/12843/4/Thesis-2013Mustapa.pd

24. Nurshuhada, Z., Lou, E., Suhaimi, M.-D. M., \& Faizul, a. R. (2013). Analysis of Practices for Private Finance Initiative (PFI) Procurement Process: Malaysia vs. United Kingdom. The Professional Journal of Royal Institution of Surveyors Malaysia, 48(1), 13-21.

25. Oyedele, L. O. (2013). Avoiding Performance Failure Payment Deductions in PFI / PPP Projects : Model of Critical Success Factors, (JUNE), 283294. doi:10.1061/(ASCE)CF.1943-5509.0000367.

26. Oyegoke, A., Khalfan, M., McDermott, P., Rowlinson, S. \& Dickinson, M., Construction Project Procurement Routes; an in-depth critique, International Journal of Managing Projects in Business, Vol. 2(3), 2009, pp. 338-354

27. Pitt, M., Collins, N., \& Walls, A. (2006). The private finance initiative and value for money. Journal of Property Investment \& Finance, 24(4), 363-373. doi:10.1108/14635780610674534

28. Robinson, H., Carillo, P., \& Anumba, C. J. (2010). Knowledge Management for Public-Private Partnerships.

29. Robinson, H. S., \& Scott, J. (2010). Construction Management and Economics Service delivery and performance monitoring in PFI / PPP projects Service delivery and performance monitoring in PFI / PPP projects, (December 2014), 37-41. doi:10.1080/01446190802614163

30. Semple, A., \& Turley, L. (2013). Public-Private Partnership Health Check: Managing partnerships during their lifetime, (February).

31. Smyth, H., \& Edkins, A. (2007). PROJECT Relationship management in the management of PFI / PPP projects in the UK, 25, 232-240. doi:10.1016/j.ijproman.2006.08.003 
32. Sundaraj, G., \& Eaton, D. (2013). Quantifying robustness in PFIs. Journal of Financial Management of Property and Construction, 18(1), 26-52. doi:10.1108/13664381311305069

33. Swaffield, L. M., \& McDonald, A. M. (2008). The contractor's use of life cycle costing on PFI projects. Engineering, Construction and Architectural Management, 15(2), 132148.doi:10.1108/09699980810852664

34. Umar, A. A., Idrus, A., Khamidi, M. F., Iskandar, B. S., \& Darul, P. (2011). Barriers to the use of Public-Private Partnerships for the provision of Public Infrastructure in Developing countries: A review.

35. Umar, A. A., Zawawi, N. A. W. A., Otairu, A., \& Othman, I. (2014). Private Finance Initiatives ( PFI ): Getting it right, 567, 601-606. doi:10.4028/www.scientific.net/AMM.567.601

36. Wang, N., \& Wang, N. (2014). Private finance initiative as a new way to manage public facilities A review of the literature. doi:10.1108/F-09-20120069

37. William.T. (2005). Moving to Public Private Partnership 